\title{
Rancang Bangun Perangkat Belajar Braille Elektronik Berbasis Raspberry P $i$
}

\author{
Hidayat $^{1}$, Muhammad Yusuf ${ }^{2}$ \\ ${ }^{1,2}$ Teknik Komputer, Universitas Komputer Indonesia, Bandung, Indonesia \\ $\underline{\text { hidayat@email.unikom.ac.id }}$
}

Diterima 7 April 2020

Disetujui 16 Juni 2020

\begin{abstract}
The aim of the present research was to design and implement a braille electronic learning device for helping children who are blind in studying. The method used was an experimental method that includes the study of literature, the design process, the process of implementing tool manufacturing and also functional testing. This is made easier for blind people to learn to arrange words in braille and translate it to english or bahasa vice versa and convert braille to speech using eSpeak application, as a very popular application with free access. The system designed consists of the Raspberry $P i$ as the main data processor, six pushbuttons as input for braille codes, five push-buttons as control buttons, external MMC memory as a storage place for the operating system documents used by Raspberry $\mathrm{Pi}$ and also as a storage place for digital information such as applications that are made and also voices and the speaker functions as voice output, and also the LCD functions to display letters or numbers entered by users, it is only intended for teachers or instructors who can see when accompanying blind students. The overall system test results produce the expected output, which can speak words or numbers and translate words in two languages (Bahasa-English) correctly.
\end{abstract}

Index Terms-Braille, Braille Electronic Learning, Braille to Speech, Raspberry Pi, Tunanetra

\section{PENDAhULUAN}

Kesempatan belajar merupakan hak bagi semua anak-anak khususnya di Indonesia, tak terkecuali anak-anak berkebutuhan khsusus, salah satunya adalah anak-anak penyandang tunanetra. Anak-anak yang memiliki keterbatasan tersebut oleh pemerintah telah disediakan fasilitas pendidikan khusus disesuaikan dengan derajat dan jenis difabelnya yang disebut dengan Sekolah Luar Biasa (SLB).

Namun, saat ini sebagian besar sarana dan alat bantu pembelajaran bagi tunanetra di SLB secara umum masih konvensional yaitu menggunakan reglet dan stylus [1]. Penulisan braille dengan perangkat tersebut harus dituliskan pada kertas khusus yang tebal agar dapat diraba oleh penyandang tunanetra pada saat belajar membaca. Proses belajar seperti memerlukan seorang guru pendamping yang memahami kode braille untuk melafalkan setiap kode braille. Sementara itu, pada penelitian [2] ditemui bahwa siswa tunanetra menghadapi beberapa keterbatasan dalam mengakses dan memanfaatkan fasilitas Teknologi Informasi dan Komunikasi (TIK) untuk meningkatkan kualitas pengalaman belajarnya. Hal ini juga dapat disebabkan karena terbatasnya perangkat aplikasi TIK yang diperuntukkan bagi penyandang tunanetra. Beberapa penelitian yang pernah dilakukan terkait perangkat belajar bagi tunanetra salah satunya adalah pada penelitian [3] yang membahas tentang pelafalan suku kata dari kode braille. Penelitian lainnya, yaitu penelitian perangkat belajar iqra dan AlQur'an [4]-[6].

Pada paper ini dibahas sebuah penelitian pengembangan pada perangkat belajar menyusun huruf dan kata secara elektronik bagi tunanetra. Oleh karena itu, sistem yang dirancang harus dapat membaca huruf, kata maupun kalimat yang dimasukkan dalam kode braille. Selain itu, perangkat juga dirancang agar dapat menerjemahkan kata maupun kalimat dalam bahasa Inggris ke Indonesia ataupun sebaliknya sebagai alat bantu belajar bahasa Inggris. Keluaran perangkat yang dirancang berupa suara pelafalan kata maupun kalimat yang dimasukkan oleh pengguna. Proses penerjemahan kata maupun kalimat ke pelafalan menggunakan aplikasi eSpeak yang merupakan aplikasi Text to Speech (TTS) yang populer untuk menerjemahkan teks ke dalam suara seperti yang digunakan pada penelitian [7] dan [8]. Selain itu, aplikasi eSpeak dapat diakses secara gratis. Adanya perangkat belajar braille elektronik yang dapat langsung dioperasikan oleh siswa tunanetra ini diharapkan dapat mengurangi ketergantungan penyandang tunanetra kepada pendamping selama melakukan belajar secara mandiri.

\section{PERANCANGAN}

Perancangan yang dilakukan terdiri dari perancangan perangkat keras dan perancangan perangkat lunak.

\section{A. Perancangan Perangkat Keras}

Pada perancangan perangkat keras ditentukan sejumlah komponen yang diperlukan untuk membangun perangkat yang akan dirancang. Sistem 
perangkat keras yang dirancang ditampilkan pada Gambar 1.

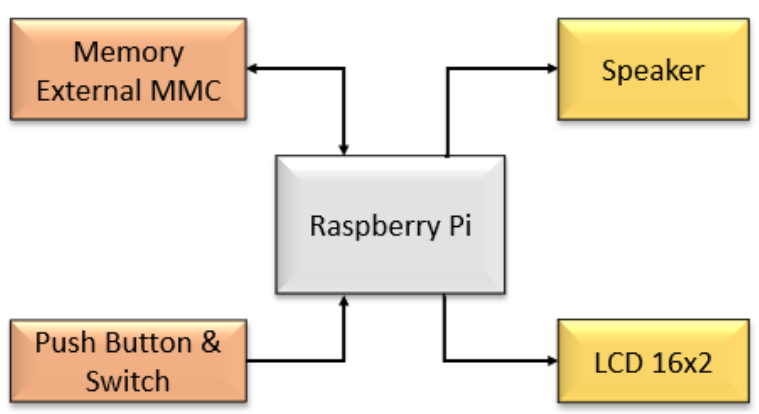

Gambar 1. Diagram blok system

Sejumlah komponen yang digunakan adalah:

- Push button, berfungsi sebagai masukan berbentuk braille untuk huruf atau angka yang akan diubah menjadi suara.

- Raspberry Pi, berfungsi sebagai pengolah data sehingga dapat melakukan pembacaan pada masukan push button dan mengeluarkannya dalam bentuk suara melalui Speaker. Raspberry merupakan sebuah 2omputer berukuran kecil yang termasuk kedalam jenis (single-board circuit; SBC)[9]. Raspberry $P i$ banyak digunakan pada banyak aplikasi sebagai pengontrol utama. Secara umum, , Raspberry $\mathrm{Pi}$ digunakan untuk sistem pengontrolan dan pemantauan [10]-[13].

- Memori External MMC, berfungsi sebagai tempat penyimpanan dokumen sistem operasi yang digunakan oleh Raspberry $P i$ dan juga sebagai tempat penyimpanan informasi digital seperti aplikasi yang dibuat dan juga suara.

- Speaker, berfungsi sebagai keluaran berbentuk suara.

- LCD 16x2, berfungsi untuk menampilkan huruf atau angka yang dimasukkan oleh pengguna, LCD ini hanya diperuntukan bagi guru atau pengajar yang dapat melihat ketika mendampingi pelajar tunanetra selama belajar.

Selain itu, sistem catu daya pada perangkat yang dirancang menggunakan baterai yang dapat diisi ulang sehingga saat penggunaan perangkat tidak memerlukan kabel yang terus tersambung pada daya listrik PLN.

Pada alat terdapat rangkaian push button yang merupakan salah satu komponen utama. Push button digunakan sebagai masukan huruf dan angka dalam bentuk kode braille yang nantinya akan diterjemahkan oleh Raspberry Pi dengan program Python yang telah dibuat. Push button disusun sesuai dengan standar mesin ketik braille bagi tunanetra [14], sehingga penyandang tunanetra dapat dengan mudah memahami letak titik braille berdasarkan push button. Gambar 2 merupakan rancangan push button yang berfungsi sebagai masukan kode braille dengan enam push button.

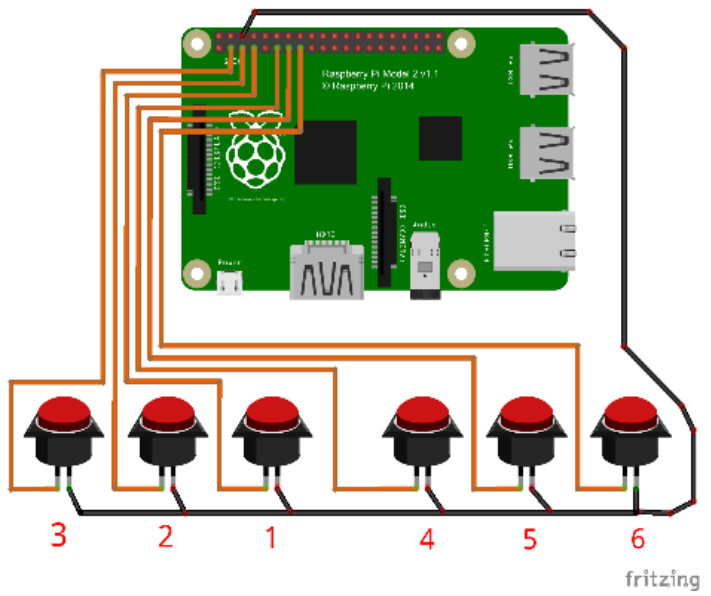

Gambar 2. Rangkaian push button kode braille

Rincian pin GPIO yang digunakan oleh tombol braille untuk terhubung dengan Raspberry $P i$ ditunjukkan pada Tabel 1.

Tabel 1. Rincian GPIO Pin untuk tombol braille

\begin{tabular}{|c|c|c|c|}
\hline No. & GPIO & No. Pin & Keterangan \\
\hline 1 & 4 & 7 & Braille Titik Nomor 3 \\
\hline 2 & 3 & 5 & Braille Titik Nomor 2 \\
\hline 3 & 2 & 3 & Braille Titik Nomor 1 \\
\hline 4 & 17 & 11 & Braille Titik Nomor 4 \\
\hline 5 & 27 & 13 & Braille Titik Nomor 5 \\
\hline 6 & 22 & 15 & Braille Titik Nomor 6 \\
\hline
\end{tabular}

Rancangan penempatan 6 tombol kode braille pada perangkat diperlihatkan pada Gambar 3.

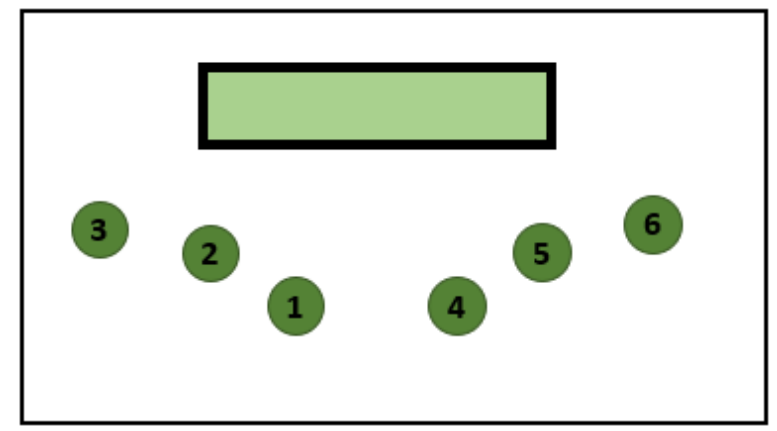

Gambar 3. Penempatan push button pada perangkat

Selain sebagai masukan yang mewakili enam titik braille, terdapat juga lima push button yang difungsikan sebagai navigasi, antara lain validasi, enter, reset, terjemah, dan juga sebagai penanda masukan angka atau huruf, selain itu juga terdapat dua 
saklar sebagai pemilihan mode dan bahasa seperti yang ditunjukkan pada Gambar 4.

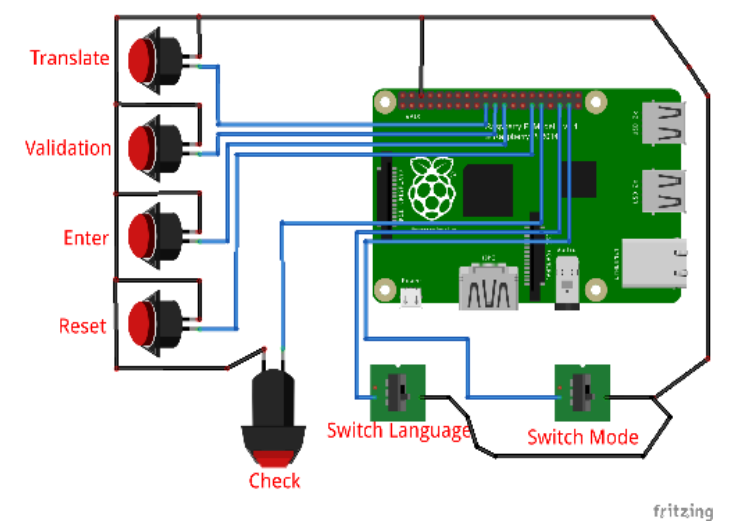

Gambar 4. Rangkaian push button dan switch sebagai navigasi

Tabel 2 merupakan rincian pin GPIO dan fungsi masing-masing tombol navigasi yang terletak pada bagian belakang perangkat.

Tabel 2. Rincian GPIO Pin untuk tombol navigasi

\begin{tabular}{|c|c|c|c|l|}
\hline No. & $\begin{array}{c}\text { Push } \\
\text { button }\end{array}$ & $\begin{array}{c}\text { GPI } \\
\text { O }\end{array}$ & $\begin{array}{c}\text { No. } \\
\text { Pin }\end{array}$ & \multicolumn{1}{|c|}{ Fungsi } \\
\hline 7 & Validasi & 9 & 21 & $\begin{array}{l}\text { Tombol untuk memvalidasi } \\
\text { jika masukan kode braille } \\
\text { yang telah ditekan }\end{array}$ \\
\hline 8 & Enter & 11 & 23 & $\begin{array}{l}\text { Tombol untuk memulai } \\
\text { pelafalan suara dari kata atau } \\
\text { angka yang disusun. }\end{array}$ \\
\hline 9 & Reset & 19 & 35 & $\begin{array}{l}\text { Tombol untuk membersihkan } \\
\text { tampilan pada LCD dan juga } \\
\text { Terminal Linux. }\end{array}$ \\
\hline 10 & Check & 6 & 31 & $\begin{array}{l}\text { Untuk menentukan masukan } \\
\text { berupa huruf atau angka }\end{array}$ \\
\hline 11 & Translate & 10 & 19 & $\begin{array}{l}\text { Tombol untuk } \\
\text { menterjemahkan kata yang } \\
\text { telah disusun }\end{array}$ \\
\hline 12 & $\begin{array}{l}\text { Switch } \\
\text { Bahasa }\end{array}$ & 5 & 29 & $\begin{array}{l}\text { Untuk memilih bahasa yang } \\
\text { akan digunakan (Indonesia / } \\
\text { Inggris) }\end{array}$ \\
\hline
\end{tabular}

Gambar 5 merupakan gambar rancangan penempatan tombol dan switch navigasi pada bagian depan perangkat.

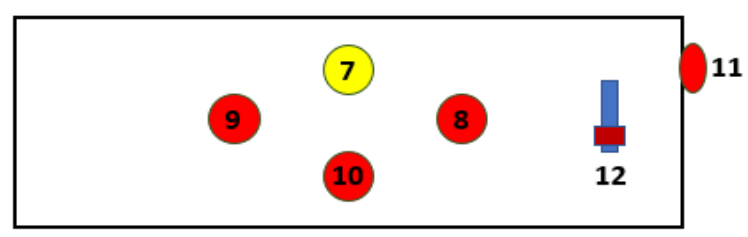

Gambar 5. Penempatan tombol navigasi pada bagian depan perangkat

\section{B. Perancangan Perangkat Lunak}

Pada bagian ini, sistem dirancang agar dapat mengubah kode braille menjadi huruf dan angka. Kode braille untuk alfabet ditunjukkan pada Gambar 6. Sementara itu, kode braille untuk angka 1 hingga 9 sama dengan kode braille untuk huruf A hingga I. Selain itu, kode braille untuk angka 0 setara dengan huruf J. Metode konversi dirancang dengan mengikuti aturan dan ketentuan untuk pembacaan braille melalui manual instruksi pada [14].
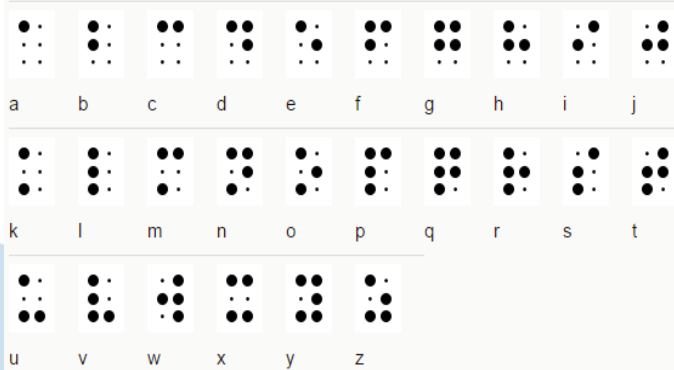

Gambar 6. Kode braille untuk huruf

Diagram alir program utama perancangan perangkat lunak pada Raspberry Pi diperlihatkan pada Gambar 7. Selanjutnya, implementasi alur program tersebut dibuat menggunakan bahasa pemrograman Python yan dijalankan pada Raspberry Pi. Selain itu, program aplikasi yang digunakan untuk melakukan pengubahan dari huruf, angka maupun kata ke dalam bentuk suara adalah program aplikasi eSpeak.

Adapun penjelasan alur program utama pada Gambar 7 adalah sebagai berikut: (1) pada tahap awal program akan melakukan proses inisialisasi pada port GPIO Raspberry $P i$ dan variabel-variabel yang digunakan dalam program utama; (2) selanjutnya, sistem akan membaca masukan pemilihan bahasa yang akan digunakan apakah bahasa Inggris atau Indonesia; pemasukan bahasa ini diperoleh dari saklar pemilihan bahasa (switch language); (3) setelah bahasa yang akan digunakan dipilih maka sistem akan mengubah bahasa yang digunakan berdasarkan pilihan; (4) pada tahap ini sistem akan mengeluarkan suara panduan penggunaan perangkat bagi pengguna; (5) selanjutnya, sistem akan mulai menjalankan prosedur Text Reader, yaitu prosedur untuk menjalankan pembacaan masukan kode braille dan melafalkan susunannya dan juga dapat melafalkan terjemahannya. 


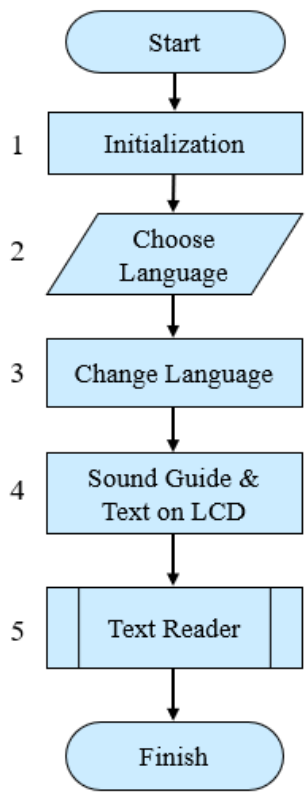

Gambar 7. Diagram alir program utama

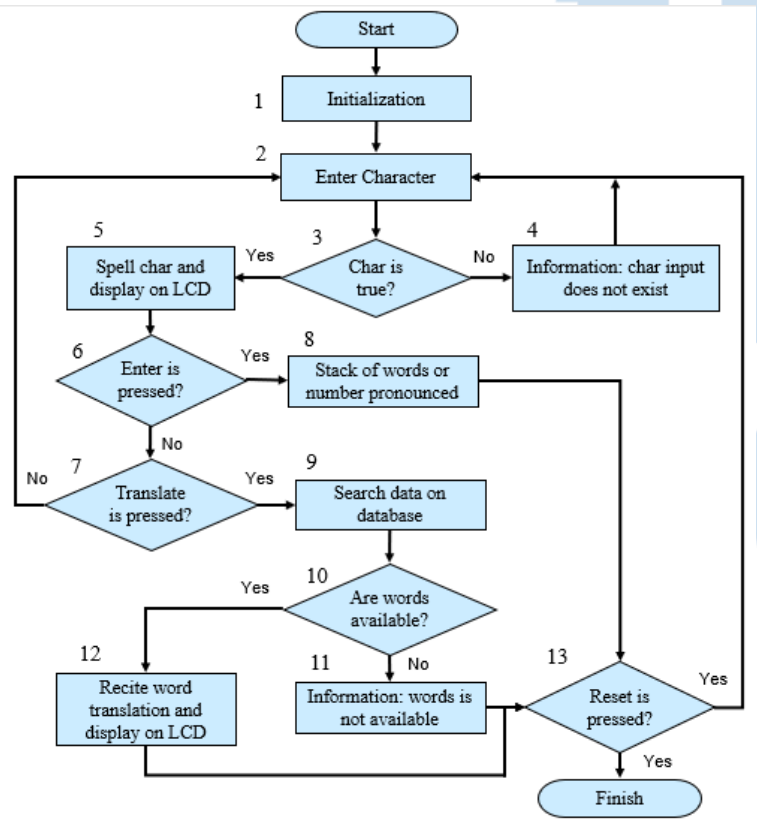

Gambar 8. Diagram alir prosedur Text Reader

Selanjutnya, diagram alir prosedur Text Reader yang menjadi bagian inti pada perangkat ini ditampilkan pada Gambar 8. Adapun penjelasan alur program prosedur tersebut adalah sebagai berikut: (1) pada tahap awal program akan melakukan proses inisialisasi pada port GPIO dan variabel-variabel yang digunakan pada bagian prosedur ini; (2) selanjutnya sistem menunggu pemasukan karakter dari push button melalui prosedur Enter Character; (3) kemudian sistem akan memeriksa apakah karakter yang dimasukkan sesuai dengan yang terdapat pada sistem atau tidak; (4) jika karakter yang dimasukkan tidak terdapat dalam sistem maka sistem akan mengeluarkan informasi kesalahan dalam bentuk suara bahwa karakter yang dimasukkan tidak tersedia pada sistem dan program akan kembali ke pembacaan karakter; (5) jika karakter yang dimasukkan terdapat pada sistem maka sistem akan menampilkan karakter tersebut pada LCD dan melafalkannya; (6) selanjutnya sistem akan membaca apakah ada penekanan tombol Enter atau tidak; (7) jika tidak tidak ada penekanan pada tombol Enter maka sistem akan membaca apakah tombol Translate ditekan atau tidak; (8) jika tombol Enter ditekan maka sistem akan menjalankan prosedur untuk melafalkan kata (susunan karakter) atau angka yang telah dimasukkan sebelumnya; (9) jika tombol Translate ditekan maka sistem akan menjalankan prosedur untuk mencari kata yang dimasukkan dalam database; (10) selanjutnya sistem akan mendeteksi apakah kata terdapat dalam database atau tidak; (11) jika kata tidak terdapat dalam database maka sistem akan memberikan informasi bahwa kata yang dimasukkan tidak terdapat dalam database sistem; (12) jika kata yang dimasukkan terdapat dalam database maka sistem akan melafalkan hasil terjemahan dari kata yang telah dimasukkan tersebut; (13) dan pada bagian akhir, sistem akan membaca

Diagram alir pemasukan karakter (Enter Character) ditampilkan pada Gambar 9. Adapun penjelasan alur program pada Gambar 9 adalah sebagai berikut: (1) pada tahap awal program akan melakukan proses inisialisasi pada Port GPIO dan variabel-variabel yang digunakan pada penekanan tombol Reset untuk memastikan program kembali ke tahap awal bagian prosedur ini; (2) selanjutnya sistem akan menjalankan pembacaan masukan karakter dari enam buah push button (push button 3, 2, 1, 4, 5, 6 yang mewakili enam titik kode braille); (3) kemudian sistem akan memeriksa apakah karakter yang dimasukkan terdapat pada sistem atau tidak setelah dilakukan penekanan tombol validasi; (4) jika karakter yang dimasukkan tidak terdapat pada sistem akan sistem akan memberikan informasi kesalahan dalam bentuk suara bahwa karakter yang dimasukkan tidak dikenali oleh sistem dan program akan kembali ke pembacaan karakter; (5) jika karakter yang dimasukkan terdapat pada sistem, sistem akan menampilkan karakter tersebut pada LCD dan melafalkannya. 


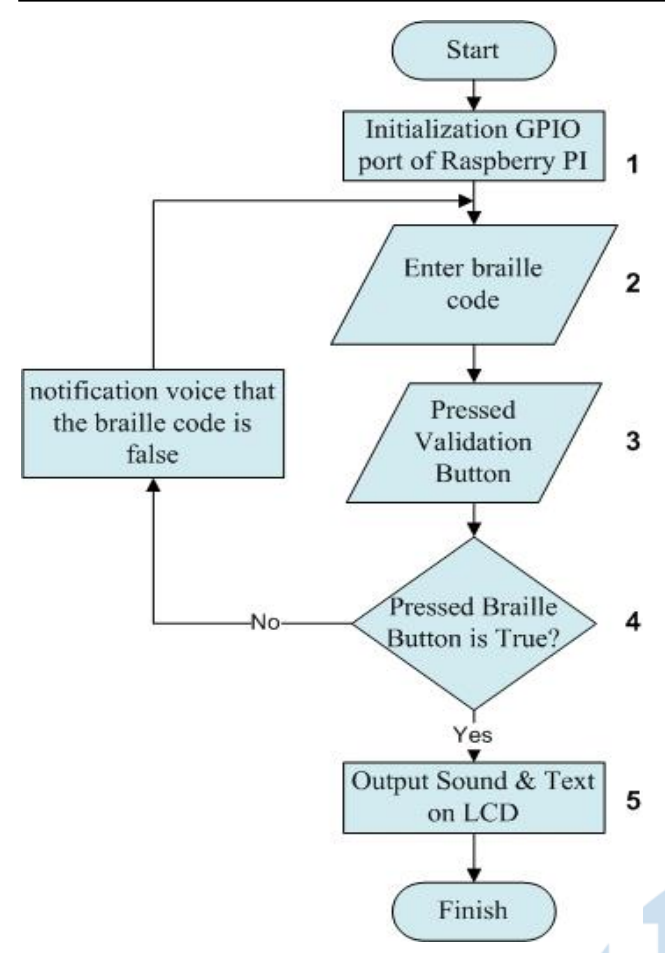

Gambar 9. Diagram alir prosedur Enter Character

\section{HASIL DAN PEMBAHASAN}

Pada bagian ini akan dibahas tentang hasil perancangan dan pengujian telah dilakukan pada perangkat. Pengujian dilakukan untuk mengetahui apakah sistem yang telah dibangun telah berfungsi dengan benar atau tidak.

\section{A. Tampilan Perangkat Keras}

Hasil rancangan perangkat keras braille electronic learning diperlihatkan pada Gambar 10.

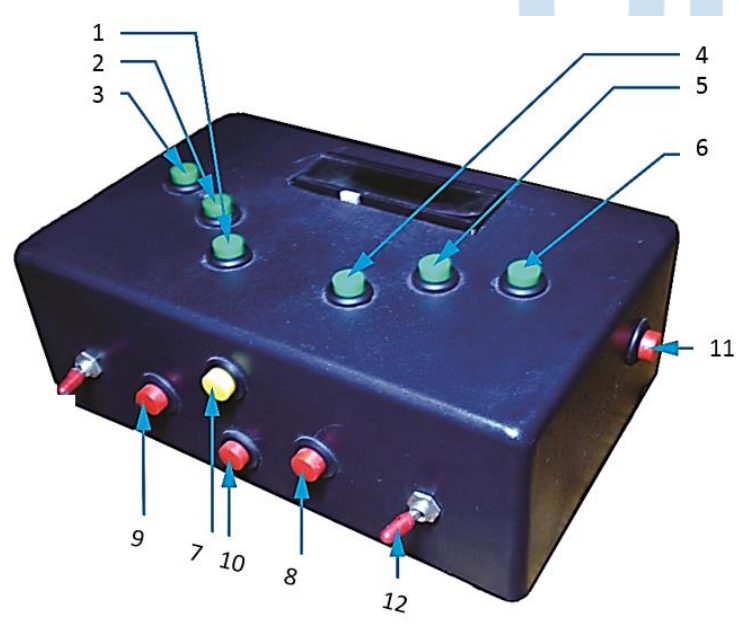

Gambar 10. Perangkat yang telah dirancang

Pada gambar 10 terdapat sejumlah push button yang digunakan untuk memasukkan karakter dalam kode braille (push button 1, 2, 3, 4, 5, 6) dan push button untuk untuk navigasi (push button 7, 8, 9, 10, 11). Penempatan push button ini disesuaikan dengan kemampuan jangkauan ujung jari-jemari pengguna. Selain itu, perangkat juga dilengkapi dengan port untuk mengisi daya baterai dan tombol power seperti ditampilkan pada Gambar 11. Sementara itu, pada Gambar 12 ditunjukkan indikator baterai penuh dan lemah serta port jack audio untuk memasangkan speaker atau earphone.

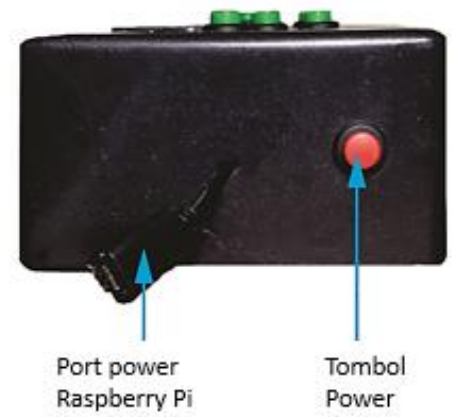

Gambar 11. Tampilan perangkat pada bagian samping kiri

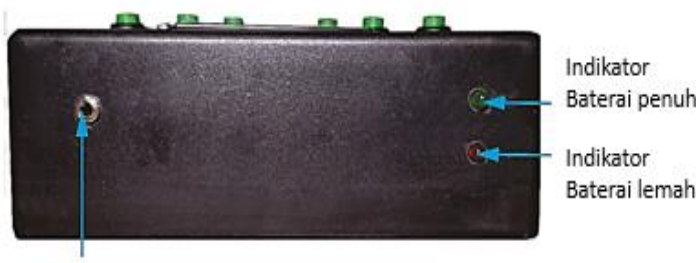

Port jack audio

Gambar 12. Tampilan perangkat pada bagian belakang

Adapun spesifikasi perangkat yang telah dibangun ditunjukkan pada Tabel 3 .

Tabel 3. Spesifikasi dari alat yang telah dibangun

\begin{tabular}{|l|l|l|}
\hline \multicolumn{2}{|l|}{ Komponen } & Spesifikasi \\
\hline Platform & Mini PC & Raspberry Pi 2 \\
\hline \multirow{2}{*}{ Display } & Tipe & LCD \\
\cline { 2 - 3 } & Ukuran & $16 \times 2$ \\
\hline Suara & $3.5 \mathrm{~mm}$ jack & Ya \\
\hline Body & Ukuran & $18 \times 11 \times 6 \mathrm{~cm}$ \\
\cline { 2 - 3 } & Berat & 538 gram \\
\hline Baterai & Kapasitas & 4 cell 8050 mAh \\
\cline { 2 - 3 } & Daya tahan & 7 jam \\
\cline { 2 - 3 } & Waktu isi ulang & 6 jam (full charger) \\
\cline { 2 - 3 } & Indikator & Ya \\
\hline \multirow{3}{*}{ Fitur } & User & Multi-user \\
\cline { 2 - 3 } & Kamus & IND-ENG-IND (5295 kata) \\
\hline
\end{tabular}




\section{B. Pengujian Pelafalan Angka, Huruf dan Simbol}

Hasil pengujian masukan angka huruf dan simbol serta pelafalannya ditunjukkan pada Tabel 4, Tabel 5 dan Tabel 6.

Tabel 4. Pengujian masukan angka

\begin{tabular}{|c|c|c|c|c|c|c|c|}
\hline \multirow[t]{2}{*}{ Angka } & \multicolumn{6}{|c|}{ Push button } & \multirow[t]{2}{*}{ Terlantunkan } \\
\hline & 3 & 2 & 1 & 4 & 5 & 6 & \\
\hline 1 & 0 & 0 & $\bullet$ & 0 & $\mathrm{O}$ & 0 & $\sqrt{ }$ \\
\hline 2 & 0 & $\bullet$ & $\bullet$ & 0 & 0 & 0 & $\sqrt{ }$ \\
\hline 3 & o & 0 & $\bullet$ & $\bullet$ & 0 & 0 & $\sqrt{ }$ \\
\hline 4 & 0 & 0 & $\bullet$ & $\bullet$ & • & 0 & $\sqrt{ }$ \\
\hline 5 & 0 & 0 & $\bullet$ & 0 & • & 0 & $\sqrt{ }$ \\
\hline 6 & 0 & $\bullet$ & $\bullet$ & $\bullet$ & 0 & 0 & $\sqrt{ }$ \\
\hline 7 & 0 & $\bullet$ & $\bullet$ & $\bullet$ & • & 0 & $\sqrt{ }$ \\
\hline 8 & 0 & • & $\bullet$ & 0 & $\bullet$ & 0 & $\sqrt{ }$ \\
\hline 9 & 0 & $\bullet$ & 0 & $\bullet$ & 0 & O & $\sqrt{ }$ \\
\hline 0 & 0 & $\bullet$ & 0 & $\bullet$ & $\bullet$ & 0 & $\sqrt{ }$ \\
\hline
\end{tabular}

Hasil pengujian angka pada Tabel 4 menunjukkan bahwa setiap angka dasar yang dimasukkan dapat dikenali oleh sistem dengan benar.

Tabel 5. Hasil pengujian masukan perhuruf

\begin{tabular}{|c|c|c|c|c|c|c|c|}
\hline \multirow[t]{2}{*}{ Huruf } & \multicolumn{6}{|c|}{ Push button } & \multirow[t]{2}{*}{ Terlantunkan } \\
\hline & 3 & 2 & 1 & 4 & 5 & 6 & \\
\hline A & O & 0 & $\bullet$ & 0 & 0 & 0 & $\sqrt{ }$ \\
\hline B & o & $\bullet$ & • & 0 & o & 0 & $\sqrt{ }$ \\
\hline $\mathrm{C}$ & O & 0 & - & - & 0 & 0 & $\sqrt{ }$ \\
\hline D & O & 0 & $\bullet$ & $\bullet$ & - & O & $\sqrt{ }$ \\
\hline $\mathrm{E}$ & O & 0 & - & 0 & - & 0 & $\sqrt{ }$ \\
\hline $\mathrm{F}$ & 0 & - & - & - & 0 & 0 & $\sqrt{ }$ \\
\hline G & o & $\bullet$ & $\bullet$ & $\bullet$ & - & 0 & $\sqrt{ }$ \\
\hline $\mathrm{H}$ & o & $\bullet$ & $\bullet$ & 0 & - & 0 & $\sqrt{ }$ \\
\hline I & 0 & - & 0 & - & 0 & 0 & $\sqrt{ }$ \\
\hline $\mathrm{J}$ & ० & $\bullet$ & 0 & $\bullet$ & - & 0 & $\sqrt{ }$ \\
\hline $\mathrm{K}$ & $\bullet$ & 0 & • & 0 & o & 0 & $\sqrt{ }$ \\
\hline $\mathrm{L}$ & $\bullet$ & - & - & 0 & 0 & 0 & $\sqrt{ }$ \\
\hline M & $\bullet$ & 0 & $\bullet$ & $\bullet$ & o & o & $\sqrt{ }$ \\
\hline $\mathrm{N}$ & $\bullet$ & 0 & • & $\bullet$ & - & 0 & $\sqrt{ }$ \\
\hline $\mathrm{O}$ & $\bullet$ & 0 & $\bullet$ & 0 & - & o & $\sqrt{ }$ \\
\hline $\mathrm{P}$ & $\bullet$ & $\bullet$ & $\bullet$ & - & 0 & 0 & $\sqrt{ }$ \\
\hline Q & $\bullet$ & $\bullet$ & $\bullet$ & $\bullet$ & - & 0 & $\sqrt{ }$ \\
\hline $\mathrm{R}$ & $\bullet$ & $\bullet$ & $\bullet$ & 0 & - & 0 & $\sqrt{ }$ \\
\hline$S$ & $\bullet$ & - & 0 & $\bullet$ & 0 & 0 & $\sqrt{ }$ \\
\hline $\mathrm{T}$ & $\bullet$ & $\bullet$ & 0 & $\bullet$ & - & 0 & $\sqrt{ }$ \\
\hline $\mathrm{U}$ & $\bullet$ & 0 & - & O & 0 & - & $\sqrt{ }$ \\
\hline V & $\bullet$ & $\bullet$ & $\bullet$ & O & 0 & $\bullet$ & $\sqrt{ }$ \\
\hline W & 0 & $\bullet$ & 0 & $\bullet$ & - & $\bullet$ & $\sqrt{ }$ \\
\hline $\mathrm{X}$ & $\bullet$ & 0 & $\bullet$ & $\bullet$ & o & $\bullet$ & $\sqrt{ }$ \\
\hline $\mathrm{Y}$ & $\bullet$ & 0 & $\bullet$ & $\bullet$ & - & $\bullet$ & $\sqrt{ }$ \\
\hline $\mathrm{Z}$ & $\bullet$ & 0 & - & 0 & - & $\bullet$ & $\sqrt{ }$ \\
\hline Spasi & - & 0 & 0 & 0 & 0 & $\bullet$ & $\sqrt{ }$ \\
\hline
\end{tabular}

Hasil pengujian huruf pada Tabel 5 menunjukkan bahwa setiap huruf yang dimasukkan dapat dikenali oleh sistem dengan benar.

Tabel 6. Hasil pengujian masukan simbol

\begin{tabular}{|c|c|c|c|c|c|c|c|}
\hline \multirow[t]{2}{*}{ Huruf } & \multicolumn{6}{|c|}{ Push button } & \multirow[t]{2}{*}{ Terlantunkan } \\
\hline & 3 & 2 & 1 & 4 & 5 & 6 & \\
\hline . & 0 & • & 0 & 0 & $\bullet$ & • & $\sqrt{ }$ \\
\hline , & 0 & • & 0 & 0 & 0 & 0 & $\sqrt{ }$ \\
\hline ; & $\bullet$ & $\bullet$ & 0 & 0 & 0 & ० & $\sqrt{ }$ \\
\hline : & 0 & $\bullet$ & 0 & 0 & $\bullet$ & 0 & $\sqrt{ }$ \\
\hline$!$ & $\bullet$ & $\bullet$ & 0 & ० & $\bullet$ & o & $\sqrt{ }$ \\
\hline$?$ & $\bullet$ & $\bullet$ & 0 & 0 & 0 & $\bullet$ & $\sqrt{ }$ \\
\hline( & $\bullet$ & - & 0 & 0 & $\bullet$ & $\bullet$ & $\sqrt{ }$ \\
\hline ) & $\bullet$ & - & 0 & 0 & $\bullet$ & $\bullet$ & $\sqrt{ }$ \\
\hline$<$ & • & $\bullet$ & 0 & 0 & $\bullet$ & $\bullet$ & $\sqrt{ }$ \\
\hline$>$ & $\bullet$ & $\bullet$ & 0 & o & $\bullet$ & $\bullet$ & $\sqrt{ }$ \\
\hline$*$ & • & 0 & 0 & 0 & • & 0 & $\sqrt{ }$ \\
\hline I & $\bullet$ & 0 & 0 & $\bullet$ & 0 & 0 & $\sqrt{ }$ \\
\hline+ & $\bullet$ & $\bullet$ & 0 & $\bullet$ & o & $\bullet$ & $\sqrt{ }$ \\
\hline- & • & 0 & 0 & 0 & 0 & • & $\sqrt{ }$ \\
\hline$\%$ & $\bullet$ & $\bullet$ & $\bullet$ & $\bullet$ & 0 & 0 & $\sqrt{ }$ \\
\hline$=$ & 0 & 0 & 0 & $\bullet$ & $\bullet$ & ० & $\sqrt{ }$ \\
\hline$\sqrt{ }$ & 0 & • & • & • & • & $\bullet$ & $\sqrt{ }$ \\
\hline
\end{tabular}

Hasil pengujian simbol pada Tabel 6 menunjukkan bahwa setiap simbol yang dimasukkan dapat dikenali oleh sistem dengan benar.

\section{Pengujian Pelafalan Kata dan Susunan Kata}

Sementara itu, hasil pengujian kata dan susunan kata atau kalimat diperlihatkan pada Tabel 7 dan Tabel 8.

Tabel 7. Pengujian pelantunan perkata

\begin{tabular}{|c|l|c|}
\hline No. & \multicolumn{1}{|c|}{ Kalimat } & Terlantunkan \\
\hline 1 & Aku & $\sqrt{ }$ \\
\hline 2 & Anda & $\sqrt{ }$ \\
\hline 3 & Kamu & $\sqrt{ }$ \\
\hline 4 & Kami & $\sqrt{ }$ \\
\hline 5 & buku & $\sqrt{ }$ \\
\hline 6 & Masih & $\sqrt{ }$ \\
\hline 7 & yusuf & $\sqrt{ }$ \\
\hline 8 & bangga & $\sqrt{ }$ \\
\hline 9 & apel & $\sqrt{ }$ \\
\hline 10 & kita & $\sqrt{ }$ \\
\hline 11 & baru & $\sqrt{ }$ \\
\hline 12 & saja & $\sqrt{ }$ \\
\hline 13 & ingin & $\sqrt{ }$ \\
\hline 14 & kamus & $\sqrt{ }$ \\
\hline 15 & sakti & $\sqrt{ }$ \\
\hline 16 & you & $\sqrt{ }$ \\
\hline 17 & we & \\
\hline 18 & hope & brother \\
\hline 19 & sister & \\
\hline 20 & & \\
\hline
\end{tabular}


ISSN 2355-3286

\begin{tabular}{|l|l|c|}
\hline 21 & will & $\sqrt{ }$ \\
\hline 22 & grandfather & $\sqrt{ }$ \\
\hline 23 & distended & $\sqrt{ }$ \\
\hline 24 & moon & $\sqrt{ }$ \\
\hline 25 & sun & $\sqrt{ }$ \\
\hline
\end{tabular}

Hasil pengujian pelafalan kata pada Tabel 7 menunjukkan bahwa sistem dapat mengenali kata dalam bahasa Indonesia dan Inggris dengan benar dan melantunkannya dengan baik.

Tabel 8. Pengujian pelantunan susunan kata

\begin{tabular}{|c|c|c|}
\hline No. & Kalimat & Terlantunkan \\
\hline 1 & milik kami & $\sqrt{ }$ \\
\hline 2 & punya saya & $\sqrt{ }$ \\
\hline 3 & bersama sama & $\sqrt{ }$ \\
\hline 4 & belum sampai & $\sqrt{ }$ \\
\hline 5 & masih berlaku & $\sqrt{ }$ \\
\hline 6 & ada disana & $\sqrt{ }$ \\
\hline 7 & hanya anda & $\sqrt{ }$ \\
\hline 8 & kurang satu & $\sqrt{ }$ \\
\hline 9 & lebih indah & $\sqrt{ }$ \\
\hline 10 & mari bergabung & $\sqrt{ }$ \\
\hline 11 & baru beli saja & $\sqrt{ }$ \\
\hline 12 & hanya ingin roti & $\sqrt{ }$ \\
\hline 13 & ingin pulang saja & $\sqrt{ }$ \\
\hline 14 & kamus indonesia & $\sqrt{ }$ \\
\hline 15 & always you & $\sqrt{ }$ \\
\hline 16 & we eat & $\sqrt{ }$ \\
\hline 17 & new game & $\sqrt{ }$ \\
\hline 18 & star wars & $\sqrt{ }$ \\
\hline 19 & so well & $\sqrt{ }$ \\
\hline 20 & i need help & $\sqrt{ }$ \\
\hline 21 & you can see & $\sqrt{ }$ \\
\hline 22 & i don't care & $\sqrt{ }$ \\
\hline 23 & ifeel you & $\sqrt{ }$ \\
\hline 24 & we will go & $\sqrt{ }$ \\
\hline 25 & strong hold & $\sqrt{ }$ \\
\hline
\end{tabular}

\begin{tabular}{|c|l|l|c|c|}
\hline 6 & abang & elder brother & ada & $\sqrt{ }$ \\
\hline 7 & abdidalemisme & sycophancy & ada & $\sqrt{ }$ \\
\hline 8 & abdikasi & abdication & ada & $\sqrt{ }$ \\
\hline 9 & aben & cremate & ada & $\sqrt{ }$ \\
\hline 10 & abjad & alphabet & ada & $\sqrt{ }$ \\
\hline 11 & babak & stage & ada & $\sqrt{ }$ \\
\hline 12 & babi & Pig & ada & $\sqrt{ }$ \\
\hline 13 & baca & Read & ada & $\sqrt{ }$ \\
\hline 14 & bacar & garrulous & ada & $\sqrt{ }$ \\
\hline 15 & cabai & Chili & ada & $\sqrt{ }$ \\
\hline 16 & cacar & smallpox & ada & $\sqrt{ }$ \\
\hline 17 & cacat & disability & ada & $\sqrt{ }$ \\
\hline 18 & cacing & Worm & ada & $\sqrt{ }$ \\
\hline 19 & Cadangan & Receve & ada & $\sqrt{ }$ \\
\hline 20 & Dabing & dubbing & ada & $\sqrt{ }$ \\
\hline
\end{tabular}

Hasil pengujian pada Tabel 9 memperlihatkan bahwa sistem dapat menerjemahkan dengan baik dan benar pada setiap akan yang dimasukkan.

\section{E. Pengujian Pelafalan Angka Lebih dari Satu Angka}

Selain itu, pengujian juga dilakukan dengan masukan angka. Hasil pengujian ini ditunjukkan pada Tabel 10.

Tabel 10. Pengujian pelantunan angka

\begin{tabular}{|c|c|c|}
\hline No. & Angka & Terlantunkan \\
\hline 1 & 10 & $\sqrt{ }$ \\
\hline 2 & 11 & $\sqrt{ }$ \\
\hline 3 & 12 & $\sqrt{ }$ \\
\hline 4 & 13 & $\sqrt{ }$ \\
\hline 5 & 17 & $\sqrt{ }$ \\
\hline 6 & 19 & $\sqrt{ }$ \\
\hline 7 & 20 & $\sqrt{ }$ \\
\hline 8 & 21 & $\sqrt{ }$ \\
\hline 9 & 27 & $\sqrt{ }$ \\
\hline 10 & 28 & $\sqrt{ }$ \\
\hline 11 & 31 & $\sqrt{ }$ \\
\hline 12 & 39 & $\sqrt{ }$ \\
\hline 13 & 41 & $\sqrt{ }$ \\
\hline 14 & 49 & $\sqrt{ }$ \\
\hline 15 & 100 & $\sqrt{ }$ \\
\hline 16 & 101 & $\sqrt{ }$ \\
\hline 17 & 120 & $\sqrt{ }$ \\
\hline 18 & 150 & $\sqrt{ }$ \\
\hline 19 & 190 & $\sqrt{ }$ \\
\hline 20 & 220 & $\sqrt{ }$ \\
\hline 21 & 290 & $\sqrt{ }$ \\
\hline 22 & 500 & $\sqrt{ }$ \\
\hline 23 & 1000 & $\sqrt{ }$ \\
\hline 24 & 1932455 & $\sqrt{ }$ \\
\hline 25 & 7638956 & $\sqrt{ }$ \\
\hline
\end{tabular}

Hasil pengujian pada Tabel 10 menunjukkan bahwa sistem dapat melantunkan angka lebih dari satu angka dengan baik dan benar. 


\section{SIMPULAN DAN SARAN}

Perancangan perangkat braille learning elektronik bertujuan agar dapat membantu belajar membaca huruf, kata dan susunan kata secara elektronik. Hasil implementasi rancangan dan pengujian pada perangkat belajar braille elektronik untuk anak-anak penyandang tunanetra menunjukkan telah berfungsi dengan baik. Perangkat yang dirancang dapat membaca semua masukan huruf, angka, simbol, kata dan susunan kata yang diujikan dengan benar serta dapat melafalkannya dengan baik. Selain itu, perangkat yang telah dibangun dapat menerjemahkan kata yang telah disimpan sebelumnya dalam database dengan benar serta dapat melantunkannya dengan baik. Tahapan selanjutnya dari hasil penelitian ini adalah bagaimana mengimplementasikan penggunaan perangkat ini kepada anak-anak penyandang tunanetra sehingga dapat dirasakan manfaatnya secara langsung.

\section{DAFTAR PUSTAKA}

[1] E. H. Kway, N. M. Salleh, and R. A. Majid, "Slate and stylus: An alternative tool for Braille writing," Procedia - Soc. Behav. Sci., vol. 7, no. C, pp. 326-335, 2010.

[2] I. Eligi and K. Mwantimwa, "ICT accessibility and usability to support learning of visually-impaired students in Tanzania Innosencia Eligi Tanzania Library Services Board. International Journal of Education and Development using Information and Communication Technology, 13(2), 87-10," Int. J. Educ. Dev. Using Inf. Commun. Technol., vol. 13, no. 2 pp. 87-102, 2017.

[3] H. Hidayat and A. Prafanto, "Electronic Voice for Set of the Syllables from Braille Code Input based on Microcontroller," Indian J. Sci. Technol., vol. 9, no. December, pp. 1-8, 2016.
[4] H. Hidayat and A. Nugraha, "Perancangan Perangkat Elektronik Media Pembelajaran Iqra dalam Kode Braille," J. Sist. Komput., vol. 5, no. 2, pp. 65-71, 2015.

[5] H. Hidayat and F. Rahmatullah, "Rancang Bangun AL-Qur'an Audio Player by Ayah (QuPA) 1.0," Maj. Ilm. Unikom, vol. 12, no. 1, pp. 53-60, 2014.

[6] H. Hidayat and L. Nurjanah, "Perancangan al-Qur'an Player untuk Tunanetra menggunakan Mikrokontroler dan DFPlayer,' Komputika J. Sist. Komput., vol. 7, no. 2, pp. 87-94, 2018.

[7] T. Zerrouki, M. M. A. Shquier, A. Balla, N. Bousbia, I. Sakraoui, and F. Boudardara, "Adapting eSpeak to Arabic language: Converting Arabic text to speech language using eSpeak," Int. J. Reason. Intell. Syst., vol. 11, no. 1, pp. 76-89, 2019.

[8] R. Kastrati, M. Hamiti, and L. Abazi, "The opportunity of using eSpeak as Text-to-Speech synthesizer for Albanian Language," in ACM International Conference Proceeding Series, 2014, vol. 883, pp. 179-186.

[9] H. Chaudhari, "Raspberry Pi Technology: A Review," vol. 2 , no. 3, pp. 83-87, 2015.

[10] M. S. D. Gupta, V. Patchava, and V. Menezes, "Healthcare based on IoT using Raspberry Pi," Proc. 2015 Int. Conf. Green Comput. Internet Things, ICGCIoT 2015, pp. 796-799, 2016.

[11] A. A. Alkandari and S. Moein, "Implementation of monitoring system for air quality using Raspberry Pi: Experimental study," Indones. J. Electr. Eng. Comput. Sci., vol. 10, no. 1, pp. 43-49, 2018.

[12]R. Shete and S. Agrawal, "IoT Based Urban Climate Monitoring using Raspberry Pi," in International Conference on Communication and Signal Processing 2016, 2016, pp. 2008-2012.

[13] V. S. Arumuga Perumal, K. Baskaran, and S. K. Rai, "Implementation of Effective and Low-cost Building Monitoring System (BMS) using Raspberry Pi," Energy Procedia, vol. 143, pp. 179-185, 2017.

[14] C. Risjord, Instruction manual for Braille transcribing, 5th ed. Washington DC: National Library Service for the Blind and Physically Handicapped., 2009. 